\title{
Valorization Strategy for Leather Waste as Filler for High-Density Polyethylene Composites: Analysis of the Thermal Stability, Insulation Properties and Chromium Leaching
}

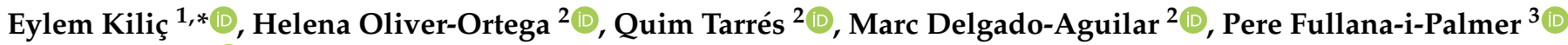 \\ and Rita Puig ${ }^{4} \mathbb{C}$
}

Citation: Kiliç, E.; Oliver-Ortega, H.; Tarrés, Q.; Delgado-Aguilar, M.; Fullana-i-Palmer, P.; Puig, R. Valorization Strategy for Leather Waste as Filler for High-Density Polyethylene Composites: Analysis of the Thermal Stability, Insulation Properties and Chromium Leaching. Polymers 2021, 13, 3313. https:// doi.org/10.3390/polym13193313

Academic Editor: Alexander B. Morgan

Received: 21 July 2021

Accepted: 17 September 2021

Published: 28 September 2021

Publisher's Note: MDPI stays neutral with regard to jurisdictional claims in published maps and institutional affiliations.

Copyright: (c) 2021 by the authors. Licensee MDPI, Basel, Switzerland. This article is an open access article distributed under the terms and conditions of the Creative Commons Attribution (CC BY) license (https:// creativecommons.org/licenses/by/ $4.0 /)$.
1 Material Science and Nanotechnology Engineering Department, Usak University, 64200 Usak, Turkey

2 LEPAMAP-PRODIS Research Group, University of Girona, 17003 Girona, Spain; helena.oliver@udg.edu (H.O.-O.); joaquimagusti.tarres@udg.edu (Q.T.); m.delgado@udg.edu (M.D.-A.)

3 UNESCO Chair in Life Cycle and Climate Change ESCI-UPF, Universitat Pompeu Fabra, 08003 Barcelona, Spain; pere.fullana@esci.upf.edu

4 ABBU Research Group, Department of Computer Science and Industrial Engineering, Universitat de Lleida (UdL), 08700 Igualada, Spain; rita.puig@udl.cat

* Correspondence: eylem.kilic@usak.edu.tr; Tel.: +90-276-2212121

Abstract: Leather waste (BF) and high-density polyethylene (HDPE) were compounded in a lab scale internal mixer and processed by means of injection molding. In this study, leather waste and HDPE composites were characterized by instrumental techniques such as differential scanning calorimetry (DSC), thermo-gravimetric Analysis (TGA), and Fourier transform infrared spectroscopy (FTIR). Physical integrity of composites against chemical exposure and chromium-leaching properties of the composites were also investigated. This study shows that the incorporation of $30 \%$ leather waste fiber into HDPE composites decreases the thermal conductivity of the composite samples by $17 \%$ in comparison to that of neat HDPE samples. Composites showed no thermal degradation during processing cycle. Strong interfacial bonding between leather waste and polymer results in comparable low-leachate levels to maximum allowed concentration for nonhazardous waste, and good chemical resistance properties. The BF/HDPE composites could be a promising low-cost alternative in industrial application areas of HDPE, where high-mechanical strength and low-thermal conductivity is required.

Keywords: leather waste; HDPE; composites; thermal properties; leaching

\section{Introduction}

The recent increasing restrictions on traditional waste treatments and the growing concerns about overexploitation of natural resources, connected with severe environmental impacts, are promoting the implementation of a circular economy. The aim of a circular economy is to minimize resource use and the associated environmental pressures by improving waste management practices through recycling, reuse of products, avoiding waste, and turning unavoidable waste into a resource. The critical discussions about implementing a circular economy and a sustainable use of natural resources led industries to focus on developing a more resource-efficient approach in their production systems.

Composite industry is one of the prominent growing sectors due to widened demand for high-performance materials and their vast usage in engineering applications, especially in the aerospace and automotive industries [1]. The industry is highly innovative and consistently searches for new material types to achieve favorable result for different applications, considering their physical properties, as well as economic and environmental performances. The considerations regarding transition towards a circular economy led composite industry to focus on renewable raw materials, which enhanced the interest in 
replacing one or all the phases of composites with more environmentally friendly components, such as natural fibers. Natural fibers provide a number of advantages compared to that of synthetic fibers, due to their abundance, availability, low-cost, and sustainability [2].

In the concept of efficient use of natural resources, the use of natural fibers derived from industrial and agricultural wastes as reinforcement material in thermoplastic polymer composites was a prominent direction of research, both in terms of valorization of agricultural wastes and recycling of industrial solid waste. Over the years, substantial research took place to develop and improve properties of natural fiber reinforced composites by using waste fibers from different plant sources (barley, peanut shell, olive hut, bamboo, etc.) [3-6]. On the other hand, comparatively fewer studies were reported using natural fiber wastes from animal origin, such as chicken feather, wool waste, and [7-9] leather waste generated in leather processing [10-12].

Leather waste is one of the major sources of animal-based collagen fibers, which provide mechanical strength and flexibility to the skin. Throughout tanning process, collagen fibers are cross-linked with tanning agents and raw skins/hides are converted into leather. Only the $20 \%$ of the rawhide is transformed into leather final product, and the $45 \%$ of raw hide is discarded in the form of nontanned and tanned collagenous waste [13]. Among the tanned collagenous wastes, the chromium containing solid waste, generated when the finished leather is subjected to abrasion process to provide a uniform feature, is referred as buffing dust (BF). BF is a micro fined powder of cross-linked collagen fibril, containing chromium, synthetic fat, and other chemicals. For every tone of skin or hide processed, approximately $2-6 \mathrm{~kg}$ of $\mathrm{BF}$ is generated as solid waste.

Contrarily to other types of leather industry solid wastes, the treatment of BF is difficult and of great environmental concern. Exposure to its particles may cause respiratory tract irritation in humans, as they contain trivalent chromium along with organic and inorganic compounds $[14,15]$. BF wastes are either incinerated or disposed to landfill sites, which account for serious environmental impacts and economic loss due to overpriced and limited available landfill sites [16]. Researchers made various attempts for finding beneficial uses of this waste and utilized BF waste as fillers for rubber [17], polylactic acid [11], and polycaprolactone [18], polystyrene [19], and epoxy-polymer [20] matrices to produce low-cost composite materials for various industrial applications (footwear industry, bags, suitcases, etc.) $[18,21]$. The literature shows that a great number and type of fillers were incorporated into HDPE to produce inexpensive HDPE composites with reduced environmental impact and enhanced properties [22], considering the wide application area and its contribution to worldwide plastic consumption [23]. Successful utilization of $\mathrm{BF}(30 \%)$ as reinforcement material in HDPE matrix resulted in superior mechanical properties, particularly improved impact resistance, and provided recyclability up to 5 recycling cycles due to strong fibrillar-like interfacial interactions between leather waste and polymer. This well-bonded system was observed and supported by SEM images in a previously published paper by our research team [24,25]. However, the literature related to thermal characteristics and chemical resistance is incipient, as well as the chromium leaching from the composites and the presence of $\mathrm{Cr}(\mathrm{VI})$ in the leachate.

For all the above, the present work aims at determining the impact of $\mathrm{BF}$ on the thermal properties of HDPE, including thermogravimetry, calorimetry and insulation, the chemical resistance and the $\mathrm{Cr}(\mathrm{VI})$ content of the leachate from composites after inducing the leaching process, which provides useful information of the end-of-life of the obtained materials.

\section{Materials and Methods}

\subsection{Materials}

Leather buffing dust waste (BF) with a particle size of the leather fiber, in the range of (0.3 $\mathrm{mm}$ diameter and $0.09 \mathrm{~mm}$ length) was provided from a sheepskin processing leather factory in Turkey. Leather waste fibers were used without any additional or prior treatment such as milling, grinding, or chemical treatment. The characteristics of BF are listed in 
Table 1 [25]. HDPE Braskem 7252 was supplied by Nexeo Solutions (Sao Paulo, Brazil) and was used as thermoplastic matrix.

Table 1. Characteristics of buffing dust waste.

\begin{tabular}{cc}
\hline Tests & Values \\
\hline Ash $(\mathrm{wt} \%)$ & 12.1 \\
Chromium $(\mathrm{III})(\mathrm{mg} / \mathrm{g})$ & 32 \\
Fatty substances $(\mathrm{wt} \%)$ & 7.9 \\
Nitrogen $(\mathrm{wt} \%)$ & 10.3 \\
Protein $(\mathrm{wt} \%)$ & 57.5 \\
Humidity $(\mathrm{wt} \%)$ & 50.9 \\
$\mathrm{pH}$ & 5.25 \\
Length average $(\mu \mathrm{m})$ & 302.8 \\
Diameter average $(\mu \mathrm{m})$ & 19.98 \\
\hline
\end{tabular}

\subsection{Method}

2.2.1. Compounding and Injection Molding of Composite Specimens

HDPE pellets and BF were dried at $80{ }^{\circ} \mathrm{C}$, before processing, to assure very low water content. Composite samples with leather fiber content from 20 to $50 \mathrm{wt} \%$ were prepared by using a Brabender®(Brabender GmbH \& Co KG, Duisburg, Germany) internal mixing machine. Materials were fed to mixing machine and compounded at $80 \mathrm{rpm}$ speed for $10 \mathrm{~min}$ at $170^{\circ} \mathrm{C}$. Thereafter, the composite blends were granulated into pellets using a blade mill equipped with a $10 \mathrm{~mm}$ mesh strainer and kept in oven (Dycometal, Barcelona, Spain) at $80{ }^{\circ} \mathrm{C}$ until further use to prevent moisture absorption. The obtained pellets were injection molded using Meteor 40 injection-molding machine (Mateu \& Sole, Barcelona, Spain) to produce dog bone composite test specimens complying with ASTM D3641 specifications.

The composite specimens were conditioned in a climatic chamber (Dycometal, Barcelona, Spain) at $23{ }^{\circ} \mathrm{C}$ and $50 \%$ relative humidity for $48 \mathrm{~h}$ before the tests were performed, according to the ASTM D618-13 (2013) and ASTM D638-14 (2014) standards.

\subsubsection{Thermogravimetric Analysis (TGA)}

Thermogravimetrical analysis (TGA) was performed using a Mettler Toledo SDTA851 thermobalance (Mettler Toledo, L'Hospitalet de Llobregat, Spain). The samples were heated from $30{ }^{\circ} \mathrm{C}$ to $700{ }^{\circ} \mathrm{C}$ at a heating rate of $10^{\circ} \mathrm{C} / \mathrm{min}$. The test was performed in an inert atmosphere with a nitrogen flow rate of $40 \mathrm{~mL} / \mathrm{min}$.

\subsubsection{Differential Scanning Calorimetry (DSC)}

Differential scanning calorimetry was performed using a Mettler Toledo DSC822 thermal analyzer (Mettler Toledo, L'Hospitalet de Llobregat, Spain) to evaluate the influence of the incorporated leather fibers on the thermal transitions and on the crystallinity degree of matrix following ASTM E1269.01 standard specifications. The samples were initially heated from 30 to $220^{\circ} \mathrm{C}$ for the first heating scan to erase their thermal history. Afterwards, cooling was performed, and the samples were heated again using the same temperature range. All runs were performed at heating or cooling rates of $10^{\circ} \mathrm{C} / \mathrm{min}$ under $40 \mathrm{~mL} / \mathrm{min}$ flow of nitrogen atmosphere.

\subsubsection{Thermal Conductivity}

Thermal conductivity of composite samples was analyzed by means of an insulated chamber equipped with four thermocouples and an electrical heating system (Honeywell, Charlotte, NC, United States) for air. This method is based on the UNE-EN 8990:1999, where the thermal transmission properties of samples are determined in steady state. The samples were positioned in the middle, dividing the chamber into two chambers (the so-called hot and the cold chambers), maintained at different temperatures in steady-state conditions. 
The thermocouples were placed at the hot chamber, and the thermal resistance of the samples was obtained by measuring the power required to keep the hot chamber at constant temperature and the temperature difference between the hot and the cold chambers. The temperature of hot side of the composite samples, the cold side of the composite samples, and the cold chamber was recorded (every minute) by means of a data acquisition system.

Thermal conductivity, was calculated using Equation (1):

$$
\lambda=\frac{e . U .(T h-T c)}{T h s-T c s}
$$

where $\lambda$ is the thermal conductivity $\left(\mathrm{W} / \mathrm{m}^{\circ} \mathrm{C}\right), e$ is the thickness of the composite sample $(\mathrm{m}), U$ is the global heat transfer coefficient $\left(\mathrm{W} / \mathrm{m}^{2}{ }^{\circ} \mathrm{C}\right)$, and $T h, T c$, Ths, and Tcs are the temperatures of the hot chamber (Th), cold chamber (Tc), hot side (Ths), and cold side (Tcs), respectively, and all in ${ }^{\circ} \mathrm{C}$. In addition to this, the $U$ was calculated from Equation (2):

$$
U=\frac{(T h-T h s)}{(T h-T c) \cdot R s i}
$$

where $R s i$ is the inner surface thermal resistance $\left(\mathrm{m}^{2}{ }^{\circ} \mathrm{C} / \mathrm{W}\right)$ and accounts for $0.13 \mathrm{~m}^{2}{ }^{\circ} \mathrm{C} / \mathrm{W}$, according to UNE-EN 8990:1999 for vertical enclosures. The temperatures of the two chambers are maintained constant and steady state conditions were kept.

\subsubsection{Fourier Transform Infrared (FT-IR) Spectroscopy}

Fourier Transformed infrared (FT-IR) measurements of BF waste, HDPE polymer and composites containing $30 \mathrm{wt} \% \mathrm{BF}$ was carried out to determine the formation and changes in the functional groups of samples. IR spectra were obtained in the frequency range of 4000 and $400 \mathrm{~cm}^{-1}$ using a Bruker Alpha FT-IR spectrometer (FT-IR) (Bruker, Madrid, Spain).

\subsubsection{Chemical Resistance Test of Composites}

Composite samples were cut into $0.5 \times 0.5 \mathrm{~cm}^{2}$ pieces and placed into specimen jar bottles, and then immersed into various chemicals (Merck, Darmstadt, Germany) such as acetone, methanol, sodium hydroxide solution $(\mathrm{NaOH}, 30 \% \mathrm{w} / \mathrm{w}$ in aqueous solution), hydrogen peroxide $\left(\mathrm{H}_{2} \mathrm{O}_{2}, 50 \% \mathrm{w} / \mathrm{w}\right.$ in aqueous solution), ethyl acetate, and acetonitrile, and left for $24 \mathrm{~h}$ to evaluate sample's resistance to each chemical. Variation at weight and change of visual appearance was examined following $24 \mathrm{~h}$ of contact with chemicals.

\subsubsection{Chromium Leaching and $\mathrm{Cr}(\mathrm{VI})$ Analysis of Composites}

To determine the extractable chromium leached from the composite sample, chromium leaching tests of composite samples incorporated with $30 \%$ of BF were performed according to ISO 17072. Extractable chromium in composite samples was determined by carrying out extraction with an acid artificial-perspiration solution and subsequent determination with inductively coupled plasma optical emission spectrometry. Solutions leached from composites samples were also analyzed for the determination of chromium (VI) content under defined conditions, in accordance with international standard ISO 17075-2.

\section{Results and Discussion}

\subsection{Thermogravimetric Analysis (TGA)}

The thermal stability of neat HDPE, leather BF waste, and 20, 30, 40, and $50 \mathrm{wt} \% \mathrm{BF}$ reinforced HDPE composites were analyzed with TGA. The results of the TGA assays and the first derivate (DTGA) are represented in Figure 1. 


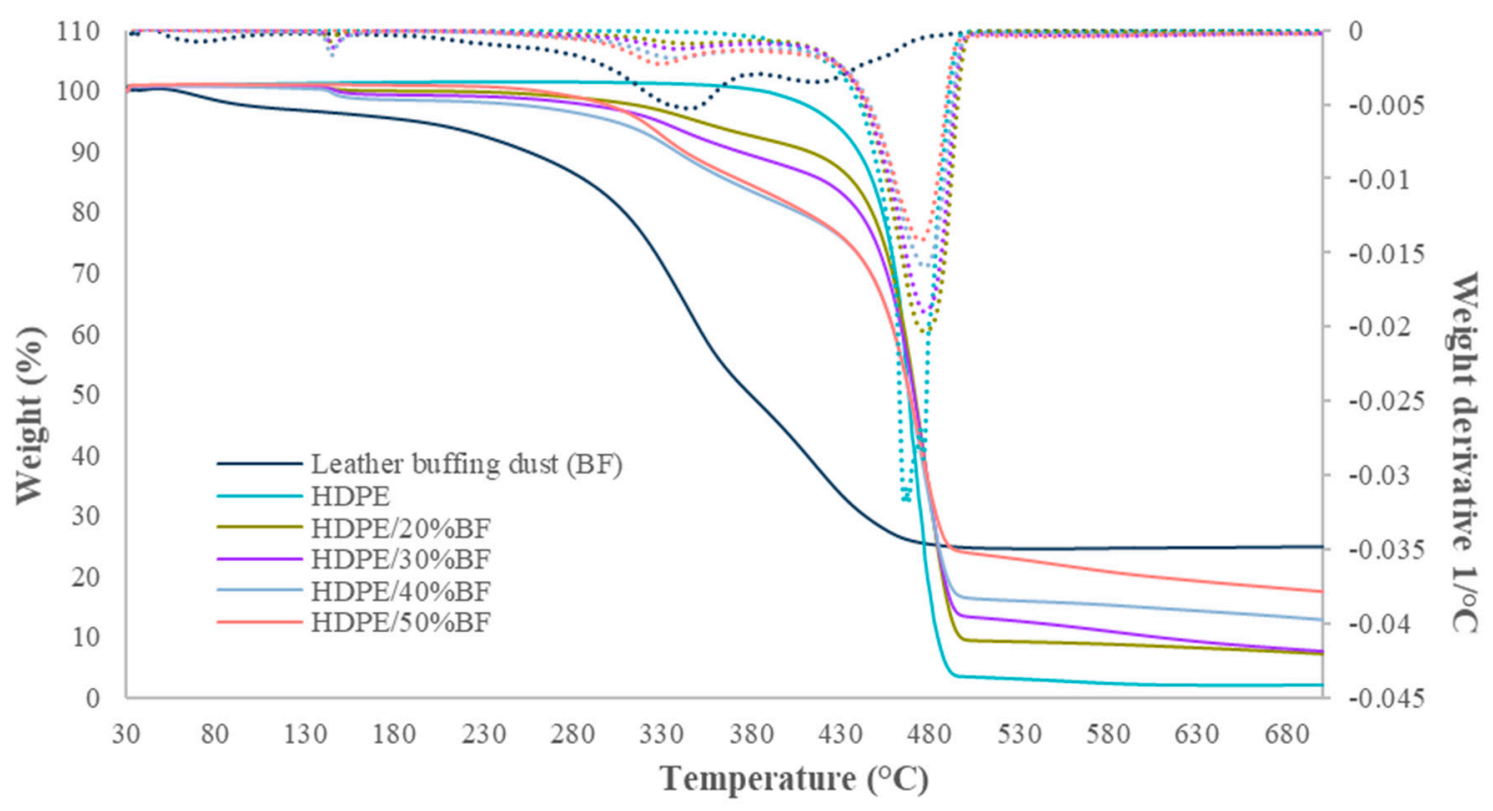

Figure 1. TGA curves and first derivate of TGA curve for neat HDPE, leather waste, and 20 to $50 \mathrm{wt} \% \mathrm{BF}$ reinforced HDPE composite materials.

The TGA figure (Figure 1) shows the mass loss against temperature, while the DTGA allows to understand better the degradation process produced for $\mathrm{BF}$ and $\mathrm{BF}$ composites sample. The BF showed a degradation mainly between 30 to $500{ }^{\circ} \mathrm{C}$, with different steps. In the DTGA, it was possible to differentiate at least 5 different processes, with the higher degradation rate around $70,235,345,415$, and $455^{\circ} \mathrm{C}$. Figure $\mathrm{S} 1$ show the different processes in the BF. The processes at 235 and $455^{\circ} \mathrm{C}$ are overlapped by the others, but the change in the curve trend seems to indicate the change in the degradation, which could be devoted with another process starting.

The BF weight loss at relatively low temperatures $\left(\mathrm{T}<100{ }^{\circ} \mathrm{C}\right)$ is due to elimination of absorbed water by leather fibers. The BF waste is rich in collagenous, a protein which tend to have a high interaction with water. The change in the mass loss tendency and the DTGA confirms the apparition of another degradation process, probably related with the protein denaturalization. The weight loss that takes place between 150 and $300^{\circ} \mathrm{C}$, with the higher rate around $235^{\circ} \mathrm{C}$, can be attributed to volatile compounds such as oil and low molecular weight greases existing in the leather fibers $[26,27]$. The third degradation process, that starts around $300{ }^{\circ} \mathrm{C}$ with a higher rate, can be assigned to the decomposition of collagen protein into intermediate compounds, in line with the previously reported studies $[18,26]$. Around $500{ }^{\circ} \mathrm{C}$, the degradation processes seem to be finished and no further weight loss is produced. Similar degradation behavior for leather fibers was observed in studies by Ambrosio et al. [27]. The residue at $700{ }^{\circ} \mathrm{C}$ accounts for a $33 \mathrm{wt} \%$.

The TGA analysis of neat HDPE matrix shows a thermally stable material up to $380^{\circ} \mathrm{C}$. Then, HDPE presents a narrow degradation step between $400-490{ }^{\circ} \mathrm{C}$. A total of $2 \mathrm{wt} \%$ residue is obtained at $700^{\circ} \mathrm{C}$. In the case of the composite material, the degradation steps of the leather $\mathrm{BF}$ became more appreciable as we increase the amount of leather $\mathrm{BF}$ in the composite materials. A small and fast degradation occurred around $150{ }^{\circ} \mathrm{C}$, which could correspond to the first degradation step of BF (excluding the water loss). Besides, the mass loss in that process is small. Around $300{ }^{\circ} \mathrm{C}$, a high loss of mass is observed, which coincides with the second and higher degradation step of BF. The next degradation of the BF, around $415^{\circ} \mathrm{C}$, seems to be overlapped with the HDPE degradation, and a single process is appreciated in composites materials.

The onset degradation temperatures for neat HDPE and composites are given in Table 2, as well as remaining mass at $700{ }^{\circ} \mathrm{C}$. Onset degradation temperature, considered in the 
range of $10 \%$ mass loss, was affected by the filler content at range from 333 to $403{ }^{\circ} \mathrm{C}$. Composite material reinforced with $40 \%$ of fiber showed slightly lower temperatures than the expected. It could be related with the presence of BF agglomerates in the tested samples, which led to a reduction of the onset temperatures. The temperature at $25 \%$ and $50 \%$ of mass loss is close to the $50 \%$ composites material, which is in agreement with a lower polymer volume and higher BF content in the tested sample. Besides, all samples have a similar trend and charred residue amount at $700{ }^{\circ} \mathrm{C}$ increased with the increased additive amount of BF content.

Table 2. Onset temperatures for $5 \%, 10 \%, 25 \%$, and $50 \%$ of weight loss and residue at $700{ }^{\circ} \mathrm{C}$.

\begin{tabular}{|c|c|c|c|c|c|c|}
\hline $\begin{array}{c}\text { Weight Loss } \\
(\%)\end{array}$ & HDPE & BF & HDPE + 20\% BF & HDPE + 30\% BF & $\mathrm{HDPE}+40 \% \mathrm{BF}$ & HDPE + 50\% BF \\
\hline 5 & 423 & 281 & 340 & 319 & 289 & 317 \\
\hline 10 & 440 & 306 & 403 & 364 & 333 & 341 \\
\hline 25 & 458 & 342 & 454 & 449 & 430 & 433 \\
\hline 50 & 469 & 408 & 472 & 471 & 468 & 471 \\
\hline Residue at $700{ }^{\circ} \mathrm{C}$ & $2 \%$ & $33 \%$ & $7 \%$ & $7.6 \%$ & $12 \%$ & $17 \%$ \\
\hline
\end{tabular}

Besides, and although the BF reduced the thermal stability of the composite materials, taking into consideration the processing temperature of neat HDPE, which is around 180-200 ${ }^{\circ} \mathrm{C}$, composites filled with BF can be processed without confronting a thermal degradation in the processing machines. The $30 \mathrm{wt} \%$ reinforced composite maintained nearly $99 \%$ of its weight at this temperature; hence, no degradation is likely to take place during the short processing cycle of the composite.

\subsection{Differential Scanning Calorimetry (DSC)}

Although the thermal stability of the composite materials in the working and manufacture range seems to not be affected by the incorporation of BF as reinforcing filler, the main transitions temperatures of HDPE could be affected. The melting and crystallization behavior of the HDPE matrix and the BF reinforced composites were studied by means of DSC. Samples were subjected to a first heat to erase the thermal history of the materials. The thermograph obtained during the second heating of HDPE and its composites shows a single endothermic process corresponding to the melting of the HDPE matrix. An amplified thermograph of the process is shown in Figure 2.

The intensity and the enthalpy of the peak is reduced during the melting process when the fiber load is increased in the composite. Nonetheless, it is due to the lower polymer content in the composite material. The results related with the filler quantity are shown in Table 3. Thus, all the materials showed a similar melting behavior with slight increase of the melting temperature when increasing the BF content. Nevertheless, the maximum increment observed was $2{ }^{\circ} \mathrm{C}$ and it is not representative; it is in concordance with the observed in the crystallinity degree of the polymer, calculated considering the enthalpy of the $100 \%$ crystallized HDPE of $293 \mathrm{~J} / \mathrm{g}[27,28]$. Only the $40 \mathrm{wt} \%$-reinforced composite showed differences in the melting enthalpy, however it could be devoted with aggregates in the sample, as above mentioned in the TGA. The incorrect dispersion of the fibers and the presence of agglomerates could affect the crystallization process as it disturbs the polymer process. Moreover, if a higher fiber content than the expected is presence in the sample it led to an incorrect enthalpy and crystallinity values because the polymer weight is lower. Thus, the presence of the BF, when it is correctly dispersed, does not seem to have any negative impact in the melting process. 


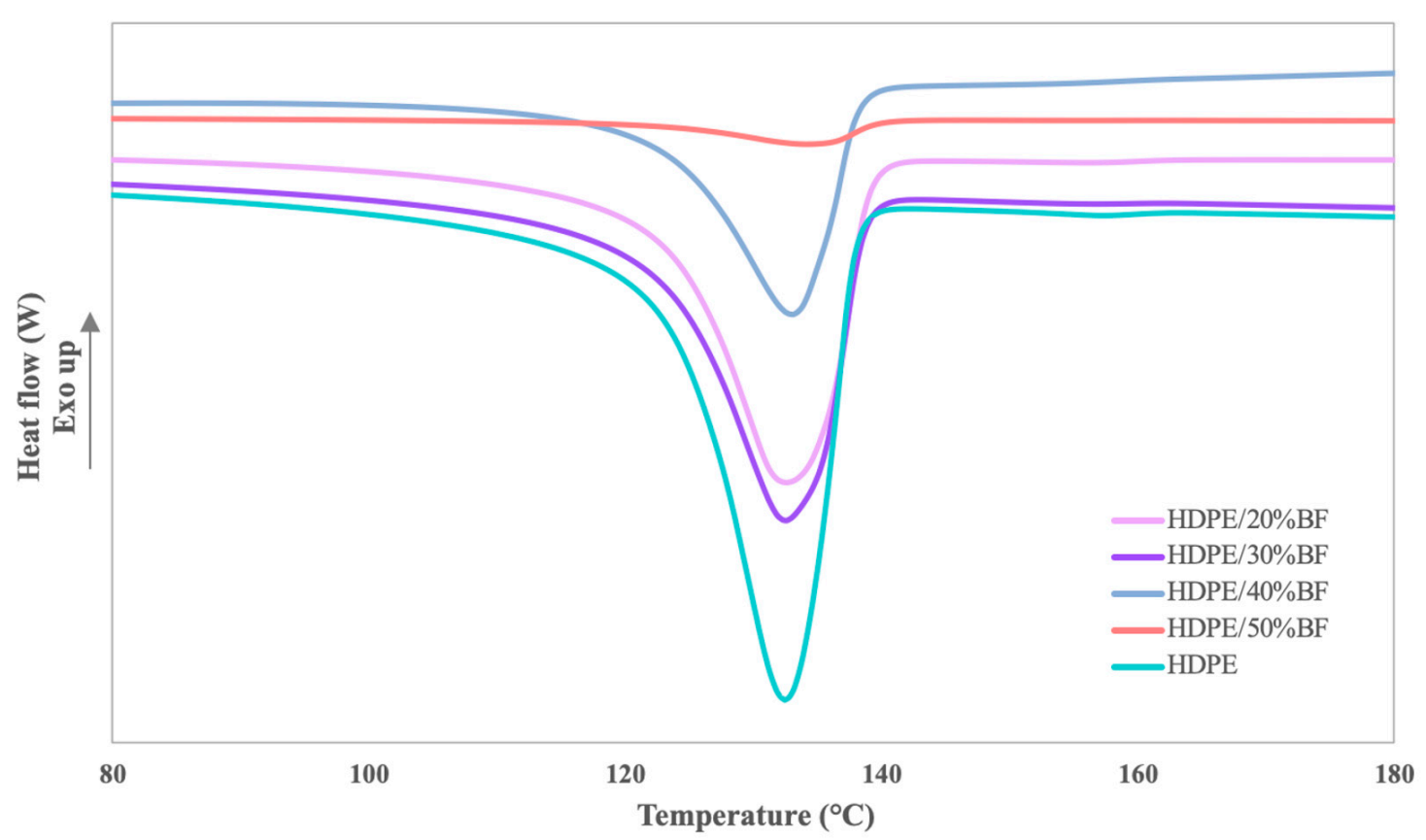

Figure 2. DSC thermographs of melting point of neat HDPE and 20 to $50 \mathrm{wt} \%$ BF-reinforced composite materials.

Table 3. Thermal transition data of HDPE and HDPE/BF composites.

\begin{tabular}{cccccc}
\hline & HDPE & HDPE + 20\% BF & HDPE + 30\% BF & HDPE + 40\% BF & HDPE + 50\% BF \\
\hline Crystallization & 117.2 & 116.4 & 117.9 & 117.4 & 114.2 \\
temperature $\left({ }^{\circ} \mathrm{C}\right)$ & 131.3 & 131.8 & 131.7 & 132.8 & 133.1 \\
Melting temperature $\left({ }^{\circ} \mathrm{C}\right)$ & 210.09 & 207.1 & 209.3 & 167.4 & 71.1 \\
Enthalpy (J/g polymer) & 71.7 & 70.7 & 71.4 & 57.1 & 71.0 \\
Crystallinity (\%) & & & &
\end{tabular}

Regarding the cooling process, the HDPE and composites materials showed also one single exothermal process related with the crystallization process of the HDPE. The peak temperatures are shown in Table 3. In general, the composite materials showed a slightly lower crystallization temperature, being the lowest at $50 \%$ of reinforced composite. The lower temperature could be associated with an easily crystallization process due to the presence of the BF fibers. Nonetheless, the differences are quite small to be considered to have a huge impact in the crystallization process.

The DSC thermograph of the 1st and the 2nd heat of the BF is shown in Figure 3. Endothermal process is observed during the first heating and is devoted to the water release of the BF. Nonetheless, around $150{ }^{\circ} \mathrm{C}$ the denaturalization of the collagen $[29,30]$ and the 1st degradation step of the $\mathrm{BF}$, observed in the TGA, are expected. A slight change of the peak related with the water is observed in the 1st heating, but the endothermal of the water evaporation is too big to account for it. Besides, a small change in the trend of the baseline is observed in the 2nd heating probably devoted to this degradation.

\subsection{Effect of Leather Waste on Thermal Conductivity of Composites Materials}

Thermal conductivity of neat HDPE and 20,30,40, and 50\% BF composite specimen were analyzed and compared. The thermal conductivity values of dry BF waste specimen (per $0.2 \mathrm{~g} / \mathrm{cm}^{3}$ ) were reported between $0.024-0.026 \mathrm{~W} / \mathrm{m}^{\circ} \mathrm{C}$ in the literature [13]. The measure accounted for a thermal conductivity of $0.200 \mathrm{~W} / \mathrm{m}{ }^{\circ} \mathrm{C}$ for HDPE, and $0.219,0.169$, 0.207 , and $0.190 \mathrm{~W} / \mathrm{m}{ }^{\circ} \mathrm{C}$ for $20 \%, 30 \%, 40 \%$, and $50 \% \mathrm{BF}$, respectively. 


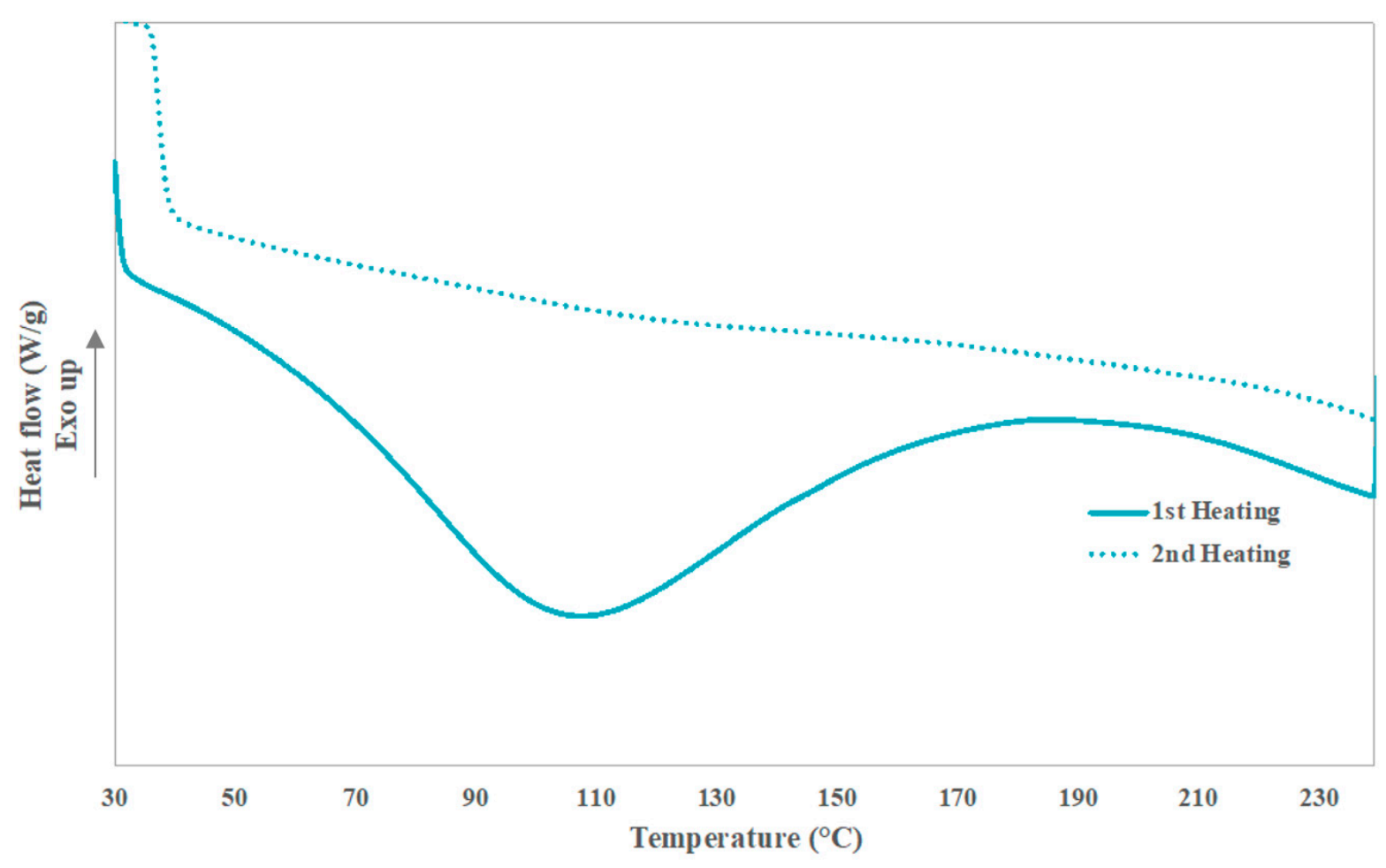

Figure 3. DSC thermograph of buffing dust waste.

Incorporation of 20,40, and 50\% protein fraction in the HDPE matrix in the form of leather waste fibers provides comparable thermal resistance to neat HDPE. On the other hand, use of $30 \% \mathrm{BF}$ improves thermal resistance for composite samples and provides a reduction of the thermal conductivity by $17 \%$ in comparison to that of neat HDPE samples. The reduction in the thermal conductivity is probably devoted to the discontinuity produced in the material by the BF fibers along with the insulation capacity of the leather $\mathrm{BF}$. The thermal conductivity values of conventional heat insulating materials range from 0.034 to $0.173 \mathrm{~W} / \mathrm{m}^{\circ} \mathrm{C}$, (for example wool has $0.037 \mathrm{~W} / \mathrm{m}{ }^{\circ} \mathrm{C}$ and wood fibers $0.107 \mathrm{~W} / \mathrm{m}^{\circ} \mathrm{C}$ ) [13]. On the other hand, thermal conductivity required for pipeline applications, which is one of the most common industrial application areas of HDPE, reported as $0.43 \sim 0.52 \mathrm{~W} / \mathrm{m}^{\circ} \mathrm{C}[31,32]$. The value of the composite materials has the potential to be used as thermal insulator and in HDPE pipeline applications.

\subsection{FTIR}

The FT-IR spectra of BF, neat HDPE, and BF/HDPE composites are given in Figure 4. HDPE shows 3 typical bands related to the symmetrical and asymmetrical $\mathrm{CH}_{2}$ rocking $\left(720 \mathrm{~cm}^{-1}\right), \mathrm{CH}_{2}$ bending $\left(1460-1470 \mathrm{~cm}^{-1}\right)$ and $\mathrm{CH}_{2}$ stretching $\left(2850-2920 \mathrm{~cm}^{-1}\right)$ [33]. Thus, the other peaks in the composite materials must be devoted to BF. BF fibers showed the bands related with the aminoacids groups of collagen. The peak at $3295 \mathrm{~cm}^{-1}$ is assigned to the characteristic of $-\mathrm{OH}$ and $-\mathrm{NH}$ stretching vibration of amino acid in leather waste, and in the literature on this band reported between 3000 and $3500 \mathrm{~cm}^{-1}[11,12,34-37]$. The bands comprised in the range $1600-1700 \mathrm{~cm}^{-1}$ and $1550-1570 \mathrm{~cm}^{-1}$ were related with amide I ( $\mathrm{C}=\mathrm{O}$ stretching of proteins) and amide II bands ( $\mathrm{C}-\mathrm{N}$ stretching and $\mathrm{N}-\mathrm{H}$ bending of proteins) also to collagen respectively [34]. As previously described in the literature, similar results were reported for BF waste by Ambone et al $\left(1625-1535 \mathrm{~cm}^{-1}\right)$, Cardona et al. (1650-1540 $\left.\mathrm{cm}^{-1}\right)$, Senthil et al (1643-1540 $\left.\mathrm{cm}^{-1}\right)$, and for chromium shaving waste by Mohamed et al. $\left(1650-1540 \mathrm{~cm}^{-1}\right)$, Li et al $\left(1645-1544 \mathrm{~cm}^{-1}\right)$, and Liu et al $\left(1647-1545 \mathrm{~cm}^{-1}\right)[11,12,35-38]$. 


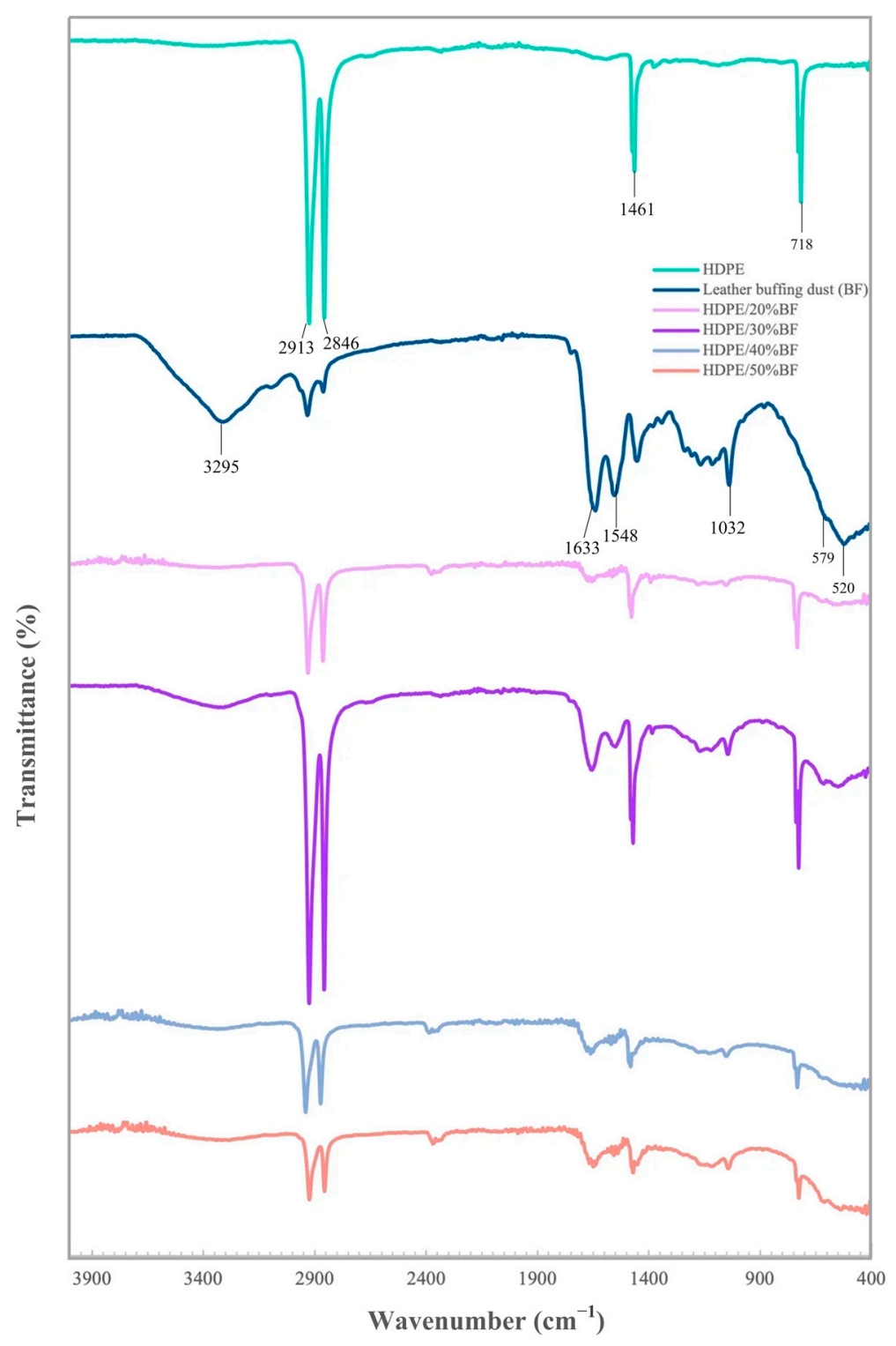

Figure 4. FTIR spectra of leather BF, HDPE and 20\%, 30\%, 40\%, and 50\% BF composite.

The weak band in region $1000-1250 \mathrm{~cm}^{-1}$ could be attributed to $-\mathrm{CN}$ and $-\mathrm{CO}$ groups of amino acids $[11,20,36,39]$. Thus, the results confirmed the presence of quantitative protein content in $\mathrm{BF}$ waste. The peak at about $520-850 \mathrm{~cm}^{-1}$ accounts for $\mathrm{Cr}$ (III) species, which is in line with previously published data by, Liu et al $\left(662-556 \mathrm{~cm}^{-1}\right)$, Cardona et al $\left(650 \mathrm{~cm}^{-1}\right)$ and Senthil et al $\left(852 \mathrm{~cm}^{-1}\right)[12,35,38]$. These bands were expected due to the $\mathrm{Cr}$ use in the leather tanning process. BF/HDPE composites showed all characteristic peaks of HDPE and BF. Of the bands at 2848-2915 $\mathrm{cm}^{-1}, 1,461 \mathrm{~cm}^{-1}$, and $718 \mathrm{~cm}^{-1}$, all three are related to HDPE. Nonetheless, the characteristic absorption of amide groups of leather slightly shifts to lower wave number and changes from $1548-1536 \mathrm{~cm}^{-1}$ and to a higher wave number from $1633-1643 \mathrm{~cm}^{-1}$ compared with that of the original leather BF. These changes could indicate interfacial interactions between HDPE and leather BF, which improve their compatibility.

\subsection{Chemical Resistance Test Results}

Chemical resistance of neat HDPE and composites containing $30 \mathrm{wt} \% \mathrm{BF}$ was investigated in terms of physical integrity and dissolution upon treatment with various chemicals. Following the treatment with chemicals, composites treated with hydrogen 
peroxide $\left(\mathrm{H}_{2} \mathrm{O}_{2} 50 \%\right)$ solution for $24 \mathrm{~h}$, dissolved some of the leather fibers from composite samples, resulting in an approximate weight loss of $10 \%$ and changed physical integrity of samples (Figure 5). Different from other chemicals used in the experiment, hydrogen peroxide is a strong oxidizer, particularly in the concentrated state.

$\%$ Weight change after chemical contact

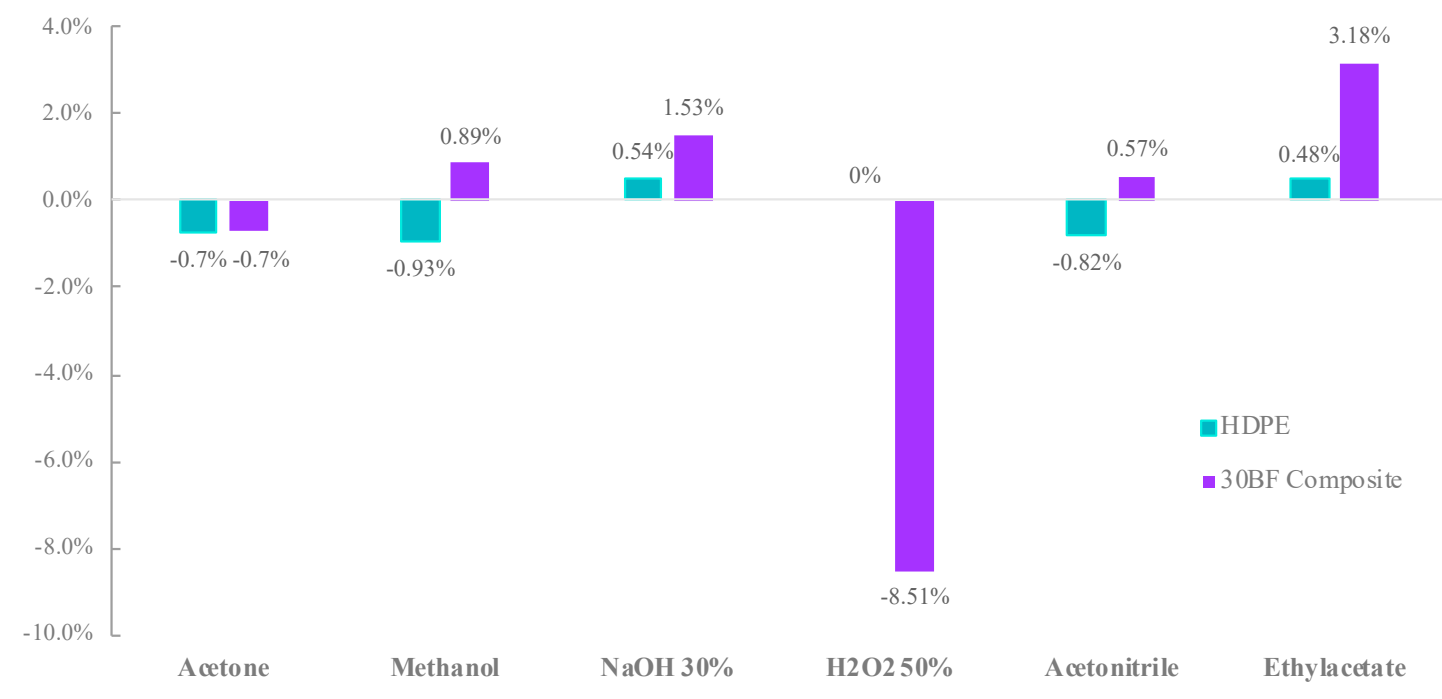

Figure 5. Relative weight change of HDPE and composite samples following $24 \mathrm{~h}$ of chemical contact.

On the other hand, composites and neat HDPE samples did not exhibit any significant change both in visual appearance and weight loss in treatments with other chemicals such as acetone, methanol, $\mathrm{NaOH}$, acetonitrile, and ethylacetate.

The oxidation state of chromium is an important indicator of toxicity and potential mobility. Chromium in the hexavalent state is highly toxic and soluble, whereas the trivalent state is much less toxic and relatively insoluble. Analysis of chromium leachate was performed to determine the mobility and the amount of extractable chromium in composites. $\mathrm{Cr}^{3+}$ in the leachate were found as $12 \mathrm{ppm}$ for $30 \%$ BF composite and $21 \mathrm{ppm}$ for $40 \%$ BF composites. The composite reinforced with a 30\% BF provides comparable low levels in leachate to maximum allowed concentration MAC for nonhazardous waste ( $\mathrm{MAC}=10 \mathrm{mg} / \mathrm{kg}$ ) [40] and previously published data regarding evolution of chromium oxide in natural rubber composites, subsequent to its exposure to different sanitizing chemicals $(50 \mathrm{mg} / \mathrm{kg}$ ) [41]. The strong interfacial bonding between polymer and leather waste, reported in our previously published paper, presumably prevented chromium leaching from composites [24]. The results for $\mathrm{Cr}(\mathrm{VI})$ suggested that the leachate contained Cr6+ at BDL (below detectable limit).

\section{Conclusions}

HDPE and animal-based natural fibers provided from leather industry waste were compounded in a lab scale internal mixer and processed through injection molding processes. The effect of leather fiber incorporation on thermal and structural properties of composites were studied in terms of TGA, DSC, and FTIR analysis. Chemical resistance and chromium-leaching properties of the composites were also investigated.

The experimental results showed that although the BF caused a slight reduction in thermal stability of the composite materials, composites filled with leather fibers from tannery waste can be processed without confronting a thermal degradation in the processing machines. The presence of the $\mathrm{BF}$ in composites does not have any impact on the melting process, and a negligible effect on crystallization process of composites due to slightly lower crystallization temperature. BF/HDPE composite showed all FT-IR characteristic 
peaks of HDPE and BF. On the other hand, incorporation of BF waste from chrome tanned leather into HDPE polymer matrix improved thermal insulation of final composite material by $17 \%$ due to thermal insulation capacity of leather fibers. Exposure of neat HDPE and composite samples to different chemicals did not exhibit any change in either visual appearance or weight of samples, except hydrogen peroxide (50\%), which is a concentrated strong oxidizer. Further, the chromium leaching tests performed on composite samples provided comparable low leachate levels to maximum allowed concentration MAC for nonhazardous waste, and chromium VI is below detection limit in all the sample leachates.

The main advantages of BF/HDPE composites are use of animal-based natural fiber from industrial waste as inexpensive filler, and there is no need for previous treatments for preparing composite samples. The BF/HDPE composites could be a promising low-cost and sustainable alternative in HDPE applications, where high-mechanical strength and heat insulation is needed. Further, the obtained results bring to the light the suitability of HDPE for encapsulating BF, which prevents the $\mathrm{Cr}(\mathrm{VI})$ leaching.

Supplementary Materials: The following are available online at https:/ / www.mdpi.com/article/ $10.3390 /$ polym13193313/s1, Figure S1: DTGA of BF from $30^{\circ} \mathrm{C}$ to $700{ }^{\circ} \mathrm{C}$

Author Contributions: Conceptualization, R.P. and M.D.-A.; Investigation, E.K. and H.O.-O.; Formal analysis, Q.T.; Resources, Q.T.; Writing-original draft, E.K. and H.O.-O.; Writing-review \& editing, P.F.-i.-P. and M.D.-A.; Funding acquisition, R.P.; Supervision, P.F.-i.-P., R.P. and M.D.-A. All authors have read and agreed to the published version of the manuscript.

Funding: This research was funded by the Spanish Ministry of Science and Innovation, project KAIROS-BIOCIR (PID2019-104925RB-C32).

Data Availability Statement: Data is available upon request to the corresponding author.

Acknowledgments: Marc Delgado-Aguilar is a Serra Húnter Fellow.

Conflicts of Interest: The authors declare that they have no known competing financial interests or personal relationships that could have appeared to influence the work reported in this paper. The funders had no role in the design of the study; in the collection, analyses, or interpretation of data; in the writing of the manuscript, or in the decision to publish the results.

\section{References}

1. Madhu, P.; Mavinakere Rangapp, S.; Jawaid, M.; Shivanna, P.; Basavegowda, Y.; Saba, N. Potential of natural/synthetic hybrid composites for aerospace applications. In Sustainable Composites for Aerospace Applications; Woodhead Publishing: Duxford, UK, 2018; pp. 315-351, ISBN 9780081021316.

2. Ku, H.; Wang, H.; Pattarachaiyakoop, N.; Trada, M. A review on the tensile properties of natural fiber reinforced polymer composites. Compos. Part B Eng. 2011, 42, 856-873. [CrossRef]

3. Serra-Parareda, F.; Tarrés, Q.; Delgado-Aguilar, M.; Espinach, F.X.; Mutjé, P.; Vilaseca, F. Biobased composites from biobasedpolyethylene and barley thermomechanical fibers: Micromechanics of composites. Materials 2019, 12, 4182. [CrossRef] [PubMed]

4. Garcia-Garcia, D.; Carbonell-Verdu, A.; Jordá-Vilaplana, A.; Balart, R.; Garcia-Sanoguera, D. Development and characterization of green composites from bio-based polyethylene and peanut shell. J. Appl. Polym. Sci. 2016, 133, 12-17. [CrossRef]

5. Navas, C.S.; Reboredo, M.M.; Granados, D.L. Comparative Study of Agroindustrial Wastes for their use in Polymer Matrix Composites. Procedia Mater. Sci. 2015, 8, 778-785. [CrossRef]

6. Posada, J.C.; Jaramillo, L.Y.; Cadena, E.M.; García, L.A. Bio-based composites from agricultural wastes: Polylactic acid and bamboo Guadua angustifolia. J. Compos. Mater. 2016, 50, 3229-3237. [CrossRef]

7. Barone, J.R. Polyethylene/keratin fiber composites with varying polyethylene crystallinity. Compos. Part A Appl. Sci. Manuf. 2005, 36, 1518-1524. [CrossRef]

8. Cheng, S.; Lau, K.t.; Liu, T.; Zhao, Y.; Lam, P.M.; Yin, Y. Mechanical and thermal properties of chicken feather fiber/PLA green composites. Compos. Part B Eng. 2009, 40, 650-654. [CrossRef]

9. Tran, C.D.; Prosencyes, F.; Franko, M.; Benzi, G. Synthesis, structure and antimicrobial property of green composites from cellulose, wool, hair and chicken feather. Carbohydr. Polym. 2016, 151, 1269-1276. [CrossRef]

10. Kılıç, E.; Puig, R.; Fullana-i-Palmer, P. Composites From Leather Industry Buffing Dust: A Review. Ann. Univ. Oradea Fascicle Text. Leatherwork 2017, 18, 149-154.

11. Ambone, T.; Joseph, S.; Deenadayalan, E.; Mishra, S.; Jaisankar, S.; Saravanan, P. Polylactic Acid (PLA) Biocomposites Filled with Waste Leather Buff (WLB). J. Polym. Environ. 2017, 25, 1099-1109. [CrossRef] 
12. Liu, Y.; Wang, Q.; Li, L. Reuse of leather shavings as a reinforcing filler for poly (vinyl alcohol). J. Thermoplast. Compos. Mater. 2016, 29, 327-343. [CrossRef]

13. Lakrafli, H.; Tahiri, S.; Albizane, A.; Bouhria, M.; El Otmani, M.E. Experimental study of thermal conductivity of leather and carpentry wastes. Constr. Build. Mater. 2013, 48, 566-574. [CrossRef]

14. Chandra, P.; Kulshreshtha, K. Chromium Accumulation and Toxicity in Aquatic Vascular Plants. Bot. Rev. 2004, 70, 313-327. [CrossRef]

15. Swarnalatha, S.; Srinivasulu, T.; Srimurali, M.; Sekaran, G. Safe disposal of toxic chrome buffing dust generated from leather industries. J. Hazard. Mater. 2008, 150, 290-299. [CrossRef]

16. Sekaran, G.; Shanmugasundaram, K.A.; Mariappan, M. Characterization and utilisation of buffing dust generated by the leather industry. J. Hazard. Mater. 1998, 63, 53-68. [CrossRef]

17. Rajaram, J.; Rajnikanth, B.; Gnanamani, A. Preparation, characterization and application of leather particulate-polymer composites (LPPCs). J. Polym. Environ. 2009, 17, 181-186. [CrossRef]

18. Joseph, S.; Ambone, T.S.; Salvekar, A.V.; Jaisankar, S.N.; Saravanan, P.; Deenadayalan, E. Processing and characterization of waste leather based polycaprolactone biocomposites. Polym. Compos. 2017, 38, 2889-2897. [CrossRef]

19. Hittini, W.; Mourad, A.H.I.; Abu-Jdayil, B. Cleaner production of thermal insulation boards utilizing buffing dust waste. J. Clean. Prod. 2019, 236, 117603. [CrossRef]

20. Sivakumar, V.; Swathi, T.R.; Mohan, R.; Mandal, A.B. Preparation and characterization of nano-reinforced leather waste fiberepoxy nano composite. J. Am. Leather Chem. Assoc. 2015, 110, 401-408.

21. Omkumar, M.; Suresh Babu, A.; Jacob Moses, A. Preparation and characterization of leather polymer composites. In Proceedings of the 20th ICCM International Conference on Composite Materials, Copenhagen, Denmark, 19-24 July 2015.

22. Civancik-Uslu, D.; Ferrer, L.; Puig, R.; Fullana-i-Palmer, P. Are functional fillers improving environmental behavior of plastics? A review on LCA studies. Sci. Total Environ. 2018, 626, 927-940. [CrossRef]

23. Singh, N.; Hui, D.; Singh, R.; Ahuja, I.P.S.; Feo, L.; Fraternali, F. Recycling of plastic solid waste: A state of art review and future applications. Compos. Part B Eng. 2017, 115, 409-422. [CrossRef]

24. Kiliç, E.; Tarrés, Q.; Delgado-Aguilar, M.; Espinach, X.; Fullana-I-palmer, P.; Puig, R. Leather waste to enhance mechanical performance of high-density polyethylene. Polymers 2020, 12, 2016. [CrossRef] [PubMed]

25. Kiliç, E.; Delgado-Aguilar, M.; Puig, R.; Fullana-i-Palmer, P. Preparation and Mechanical Characterization of HDPE-Leather Waste Composites. In Proceedings of the 4th International Leather Engineering Congress, Innovative Aspects for Leather Industry, İzmir, Turkey, 19-20 October 2017.

26. Madera-Santana, T.J.; Torres, A.C.; Lucero, A.M. Extrusion and mechanical characterization of PVC-leather fiber composites. Polym. Compos. 1998, 19, 431-439. [CrossRef]

27. Ambrósio, J.D.; Lucas, A.A.; Otaguro, H.; Costa, L.C. Preparation and characterization of poly (vinyl butyral)-leather fiber composites. Polym. Compos. 2011, 32, 776-785. [CrossRef]

28. Batista, N.L.; Helal, E.; Kurusu, R.S.; Moghimian, N.; David, E.; Demarquette, N.R.; Hubert, P. Mass-produced graphene-HDPE nanocomposites: Thermal, rheological, electrical, and mechanical properties. Polym. Eng. Sci. 2019, 59, 675-682. [CrossRef]

29. Bazrafshan, Z.; Stylios, G.K. A novel approach to enhance the spinnability of collagen fibers by graft polymerization. Mater. Sci. Eng. C 2019, 94, 108-116. [CrossRef] [PubMed]

30. Zhang, Y.; Chen, Z.; Liu, X.; Shi, J.; Chen, H.; Gong, Y. SEM, FTIR and DSC Investigation of Collagen Hydrolysate Treated Degraded Leather. J. Cult. Herit. 2021, 48, 205-210. [CrossRef]

31. Song, Y.; Yao, Y.; Na, W. Impacts of Soil and Pipe Thermal Conductivity on Performance of Horizontal Pipe in a Ground-source Heat Pump. In Proceedings of the 6th International Conference for Enhanced Building Operations, Shenzhen, China, 6-9 November 2006.

32. Industrial Blansol. Available online: https://www.blansol.com/pex-multilayer/multilayer-pipe-pexalpex/ (accessed on 2 June 2021).

33. Maheswari, C.U.; Reddy, K.O.; Muzenda, E.; Shukla, M.; Rajulu, A.V. A Comparative Study of Modified and Unmodified High-Density Polyethylene/Borassus Fiber Composites. Int. J. Polym. Anal. Charact. 2013, 18, 439-450. [CrossRef]

34. Riaz, T.; Zeeshan, R.; Zarif, F.; Ilyas, K.; Muhammad, N.; Safi, S.Z.; Rahim, A.; Rizvi, S.A.A.; Rehman, I.U. FTIR analysis of natural and synthetic collagen. Appl. Spectrosc. Rev. 2018, 53, 703-746. [CrossRef]

35. Cardona, N.; Velásquez, S.; Giraldo, D. Characterization of Leather Wastes from Chrome Tanning and its Effect as Filler on the Rheometric Properties of Natural Rubber Compounds. J. Polym. Environ. 2017, 25, 1190-1197. [CrossRef]

36. Mohamed, O.A.; El Sayed, N.H.; Abdelhakim, A.A. Preparation and characterization of polyamide-leather wastes polymer composites. J. Appl. Polym. Sci. 2010, 118, 446-451. [CrossRef]

37. Li, C.; Feng, X.; Ding, E. Preparation, Properties, and Characterization of Novel Fine Leather Fibers/Polyvinyl Alcohol Composites. Polym. Compos. 2015, 36, 1186-1194. [CrossRef]

38. Senthil, R.; Hemalatha, T.; Manikandan, R.; Das, B.N.; Sastry, T.P. Leather boards from buffing dust: A novel perspective. Clean Technol. Environ. Policy 2015, 17, 571-576. [CrossRef]

39. Senthil, R.; Inbasekaran, S.; Gobi, N.; Das, B.N.; Sastry, T.P. Utilisation of finished leather wastes for the production of blended fabrics. Clean Technol. Environ. Policy. 2015, 17, 1535-1546. [CrossRef] 
40. Popita, G.E.; Rosu, C.; Manciula, D.; Corbu, O.; Popovici, A.; Nemes, O.; Sandu, A.V.; Proorocu, M.; Dan, S.B. Industrial tanned leather waste embedded in modern composite materials. Mater. Plast. 2016, 53, 308-311.

41. Ruiz, M.R.; Cabreira, P.L.S.; Budemberg, E.R.; Dos Reis, E.A.P.; Bellucci, F.S.; Job, A.E. Chemical evaluation of composites natural rubber/carbon black/leather tannery projected to antistatic flooring. J. Appl. Polym. Sci. 2016, 133, 1-10. [CrossRef] 